\title{
Transitivity Analysis of BBC and CNN Political News' Headlines about Christchurch Mosque Massacre in New Zealand: A Stylistic Perspective \\ https://doi.org/10.33806/ijaes2000.21.1.5
}

\author{
Mohammed Al- Badawi and Ibrahim Al Najjar \\ Zarqa University, Jordan
}

\begin{abstract}
The present study aims at investigating the style of reporting in the political news headlines. It deals with the headlines that tackle the issue of the Christchurch Mosque Massacre in New Zealand, 2019 from two Western news agencies, namely BBC and CNN online websites. The objective of this study is to illustrate how a reader can capture the experience by attending to the author's style and linguistic choices. The data of the study was collected, classified, segmented, and further analysed in terms of the six types of processes of Halliday's (2004) transitivity system to Systemic Functional Linguistics (SFL). The results showed that the verbal processes dominate the other types of processes, which helps at putting thoughts into words. It was also found that the style of modeling verbal experiences in news reporting serves to facilitate the attribution of the given information to authentic sources i.e. officials and eyewitnesses. However, other types of processes such as: material and mental processes are stylistically used in order to construe quantum of changes in the physical world and in the world of consciousness. While the behavioral processes help the news' reporters to make sense of human physical actions or reactions towards the event that are psychologically motivated.
\end{abstract}

Keywords: political news headlines, style, stylistics, systemic functional linguistics, transitivity

\section{Introduction}

By using language, people can transmit complicated thoughts to one another across vast reaches of space and time. One can achieve this end by using the forms of language and grammatical structures, among other things, in a meaningful way. The use of language can express the physical or abstract experiences of the real world around us i.e. the depiction of reality in our minds. Therefore, there can be various different worldviews of an event. In short, according to Halliday (2004) there are different ways of representing the same 'happening' by using different grammatical systems that language offers. When language is used in such a way, it fulfills 'the experiential function', which is seen as an important marker of style that emphasises the concept of 'style as choice'. This choice, however, has a major impact on the way discourse is shaped and interpreted (Simpson, 2014). The grammatical aptitude for capturing experience in language is seen through Halliday's system of transitivity. Halliday (2004) views transitivity as the experience and interpersonal relationships that are transformed into meanings, and in turn, the meaning is transferred into wording. In this sense, the transitivity system interprets the world 
of experience into a manageable set of processes, each construing its own model of a particular domain of experience. Halliday (1994: 106) states that,

The reality is made up of processes of going on, happening, doing, sensing, meaning, being and becoming. Transitivity is concerned with each clause in a text. It asks who are the actors, who are acted upon, and what processes are involved in the action.

This study aims at tackling the issue of the Christchurch Mosque Massacre in New Zealand in 2019, which represents the real world, and the context under examination is the political discourse. Specifically, it tackles the headlines that deal with the issue from two selected news agencies in order to observe the experiential, expressive and relational values in them. According to Radio New Zealand Website (2019), the Christchurch Mosque Massacres were two terrorist attacks that targeted mosques in Christchurch, New Zealand. The attacks resulted in the killing of 51 people and the injuring of 49 others. The New Zealand government has established a royal commission of inquiry into its security agencies in the wake of the attacks. The scope of this study falls into stylistics, which emphasises the concept of 'point of view' that refers to the "psychological perspective through which a story is told" and accounts for the basic viewing position which is adopted in a text (Simpson 2003:4). It aims at examining the news agencies' style of headlines reporting through Halliday's (2004) system of transitivity. In the section below, a review of related literature is provided.

\section{Literature Review}

The emphasis of this section is on studies tackling transitivity analysis. The researchers looked at different studies that investigated the issue in various contexts. These studies were arranged chronologically in order to trace the development of the topic over time.

Seo (2013) studied the headlines that tackled the Libyan civil war of 2011 from The British Daily Newspaper and The Chinese National Daily Newspaper. Halliday's transitivity system was used to analyse the data. The results of the study showed that the difference between these two agencies is affirmed in the discursive choices in their headlines. On the one hand, The British Daily Newspaper tended to highlight headline types with the material processes, while providing more evaluative summary headlines. On the other hand, The Chinese National Daily Newspaper maintains its context as a third-party, adhering to the Chinese ideology of non-interference. In addition, the study highlighted the concepts of positive self and negative other, which are construed in accordance with the national positions of these two different newspapers in the global political power.

In a similar vein, Miranti (2014) compared and contrasted two reports from The New York Times and The Washington Times that address the issue of immigration. The study aimed at figuring out the types of processes and participants derived from the system of transitivity in order to find out the pattern of transitivity that construes power and ideology in texts. The selected reports were segmented into clauses and analysed in terms of process types. The results showed that the 
material process is the most frequent among the other types. The participants in The New York Times editorial were projected as victims and attributed positively which in turn reflects their liberal bias. Whereas in The Washington Times, they were portrayed as troublemakers and attributed negatively which reflects their conservative bias.

Jin (2015) combined the system of transitivity with critical discourse analysis in his study. He employed a critical analysis to observe the linguistic forms of discourse and how ideology influences discourse as well as how discourse affects ideology from different angles. The researcher adopted the functional model of Halliday (2004) and Fairclough's (2013) model of critical discourse analysis to make a quantitative and qualitative analysis of American news regarding the Diaoyu Islands dispute. The researcher collected eight news reports from TIME magazine in 2012. Three main dimensions of Fairclough were classified in this research, namely, texts, interactions, and contexts. Moreover, three metafunctions of systemic functional linguistics by Halliday were classified, namely, ideational metafunction, interpersonal metafunction, and textual metafunction. In terms of the analytical tools, transitivity, transformation, and modality are used. The researcher concluded that the American media distorts the facts through word choices, the ordering of phrases, speech representation, and their selection of auxiliary verbs.

Consequently, Ong'onda (2016) investigated the system of Halliday's transitivity in a different context to identify how a certain group called Al Shabaab - an affiliate Somalia based terrorist organization - (New York Police Department, 2013) was portrayed in the news headlines that tackle the issue of the terrorist attack on the Westgate Mall in Kenya. The headlines were collected from The Daily Notion and Standard Newspaper in the period $22^{\text {nd }}$ to $27^{\text {th }}$ September 2013. The selected headlines were analysed through segmenting them into clauses and identifying the types of processes, participants, and circumstances. The findings showed that material and relational processes dominate the other types, which in turn indicate that the whole process of terrorism is mainly concerned with actions and events. It is also found that the grammatical choices in newspaper reports played an important role to express the reporters' perspectives towards Al Shabaab, which affects the readers' opinions.

A year later, Maghfiroh (2017) explained the process types of transitivity analysis in the headlines of The Jakarta Post that were published between May $1^{\text {st }}$ - May $31^{\text {st }} 2017$. They were collected by selecting, reading, and identifying them. The researcher divided the headlines into clauses in order to figure out the types of processes in each one of them and further explained each type that was found in the headlines. Unlike Ong'onda (2016), the study revealed that the behavioral process dominates the news headlines, which reports events and accidents. Therefore, the selected news agency tended to refer to the physiological and psychological processes and emphasises more on informative clauses.

Recently, Abbas and Talaat (2019) utilised Halliday's transitivity to investigate how men and women are represented in the Pakistani English newspapers depicting crime against women in addition to the different roles that are assigned to them. In order to collect the data, the researchers chose headlines of 
seven events about crimes committed against women from three Pakistani English newspapers i.e. Dawn, The Nation, and The News in the period 2005 - 2016. The analysis showed that the most frequent type of processes is the material and the newspapers employed both active and passive voice structures in their headlines. However, the newspapers tended to hide the identity of the crime doer(s) by referring to his/their financial condition, gender, and paternal relation while they used gender-orientated words and real names with regard to the women who are reported to be affected by the crimes in the selected headlines.

It can be seen that in the previous studies Halliday's framework of transitivity has provided useful insights about the stylistic discursive choices and their ideological representations in the concerned contexts. This motivates the present researchers to conduct the study on the Christchurch Mosque Massacre to investigate the stylistic choices of the concerned news agencies and their ideological motivations. Furthermore, there are some similarities between the conclusions in the previous studies. For instance, in the studies of Miranti (2014), Ong'onda (2016), and Abbas \& Taalat (2019) the material processes are found to be dominant over other types of processes, which is justified by the contexts of investigations in relation to immigration victims, Al Shabaab terrorist organizations, and crimes against women, which are mainly seen as a conceptualization of actions and events. Despite the vast area of research that relates to political discourse in the context of the Western media, what is significant about the particular context of this study is that Muslims were portrayed from a different dimension in the media whereby they are being victimized rather than projected as terrorists. In the section below, the system of transitivity is discussed as the theoretical framework for the analysis of the data of this study.

\section{The System of Transitivity}

This section provides the theoretical framework adopted in this study. It illustrates the theory of Systemic Functional Linguistics, namely Halliday's system of transitivity. The emergence of Halliday's functional grammar has led to a different view of grammatical analysis in linguistics.

Halliday (2004) focuses on the function rather than the structure. For him, language is a network of systems of options for making meaning. In his functional theory, Halliday (2004: 25) argues, "experience and interpersonal relationships are transformed into meanings and the meaning is transformed into wording." Thus, according to Halliday, the clause consists of three interrelated metafunctions, namely, ideational, interpersonal, and textual. Each metafunction is concerned with meaning, and each meaning "forms part of a different functional configuration, making up a separate stand in the overall meaning of the clause." (ibid) According to Halliday (2004), constructing experience is considered as a third line of meaning in the clause among two other lines. The other lines are the textual line of theme/ rheme (the clause as a message) and the interpersonal line of mood/ residue (the clause as an exchange). According to Halliday (2004), transitivity is seen as a grammatical system that considers how the mode of reflection or imposing order in the clause on the endless variation and flow of events is achieved. It interprets the 
world of experience into a manageable set of processes, each construing its own model of a particular domain of experience. Transitivity picks out on three key components, these are the process, the participant, and the circumstance. The process element is realised by a verbal group, the participant element is realised by a nominal group, and the circumstantial element is realised by an adverbial group or a prepositional phrase.

The processes lie between three main types and three minor types of experience. The first is the outer experience, that of which we experience the goings-on in the world around us. It is the experience of events and actions, the things people or actors do or make happen. It is realised by the material process. The second one is the inner experience, through which we experience goings-on inside ourselves, in the world of consciousness. It is realised by the mental process. The third is a sub-type of experience, which is realised by a main type of process; it is called relational clauses that relate to identifying and classifying. Therefore, the three main types are:

1. The Material process that is concerned with the outer experience.

It has two participant roles: the actor (the one who does the action) which is an obligatory element, and the goal (the entity affected by the action) which is an optional element.

2. The Mental process that is concerned with the inner experience. It has two participant roles: the senser (the one who sees, believes, wants or likes), and the phenomenon (which is, perceived, felt, wanted or liked).

3. The Relational process of identifying (token/value) and classifying (carrier/ attribute).

In addition to the three minor types which are:

1. The behavioural process which is located on the borderline between the material and mental processes, and represents the outer semblance of inner workings; the acting out of the process of consciousness, either by a psychological state, (e.g., he is laughing) or by a physiological one, (e.g., he is sleeping). The main participant that is associated with the behavioural process is the behaver (a conscious being that is behaving).

2. The verbal process, which is located on the borderline between the mental and relational processes. It is considered as a symbolic relationship constructed in human consciousness and enacted through language, like saying and meaning. The participants that are associated with the verbal process are the sayer (the entity responsible for verbal process), the receiver (the person at whom the verbal process is directed), and the verbiage (the nominalized statement of the verbal process).

3. The existential process, which is located on the borderline between the relational and the material processes. It is concerned with the existence, which is recognised to 'be', 'exist' or 'happen'. The main participant that is associated with the existential process is the existent (the entity or event which is being said to exist). 
In each type of process, there is at least one participant, though some types have more than one, involved in the process and circumstances associated with it. The nature of this varies according to the type of the process. The circumstantial elements are almost optional argumentations. Therefore, each clause consists of process, participant(s), and (optional) circumstantial elements. These circumstances are:

1.Enhancing which is a sub-type of expansion of extent and location, which construe the unfolding of the process in space and time.

2.Elaborating which is a sub type of expansion that construes the meaning of 'be' and 'become' circumstantially. It corresponds to the attribute or value of a relational process.

3.Elaboration: extending, considered as a form of joint participation in the process and represents the meanings 'and' or 'not'. It is realised by, 'with', 'without', 'instead of', 'beside'. etc.

4.Projection: it is either,

A. Matter: it is related to the verbal process and is equivalent to the verbiage, which is described, referred to, or narrated. It is realised by prepositions, such as: 'about', 'concerning', 'with reference to', sometimes simply 'of'.

B. Angle: it is related either to the sayer with the sense of 'as says' in the verbal process, or to the senser of a mental process with the sense of 'as ... think'.

The next section discusses the methodology of this study.

\section{Methodology}

This study mainly follows a qualitative approach. It employs Halliday's system of transitivity to shed light on the style of reporting and the different interpretations of the news. The data of this study consists of 15 online news headlines covering the Christchurch Mosque Massacre, from two news agencies, namely, BBC and CNN. The data was published online in the period $15^{\text {th }}$ and $25^{\text {th }}$ of March 2019 using the following keywords to filter out the search results: Christchurch Mosque Massacre, and Christchurch shootings. The news agencies were chosen because of their international popularity. Their popularity was judged based on the number of monthly visits according to Similarweb.com, therefore, this leads to their representativeness and the major impact on the audience. Similarweb is a website that monitors eighty-million websites to empower the users with the insights needed for marketing. In 2019, similarweb reported that the CNN has 532.4 million and the $\mathrm{BBC}$ has 375.8 million as an average of their monthly visits, as illustrated in Table 1 below. 
Table 1: Monthly visits of the selected news agencies according to Similarweb.com (2019)

\begin{tabular}{|c|c|c|}
\hline Agency & CNN & BBC \\
\hline Monthly Visits & 532.4 million & 375.8 million \\
& & \\
\hline
\end{tabular}

The data analysis process consisted of the following stages: first, reading the headlines then segmenting them into clauses and finally conducting transitivity analysis showing the types of process and participants' roles in each clause that would build up and construct the style of the headlines.

\section{Results and Discussion}

The analysis showed that the most frequent type of processes in the data was the verbal, followed by the material, behavioural, relational, mental, and existential respectively. All will be discussed accordingly. See Figure 1 below.

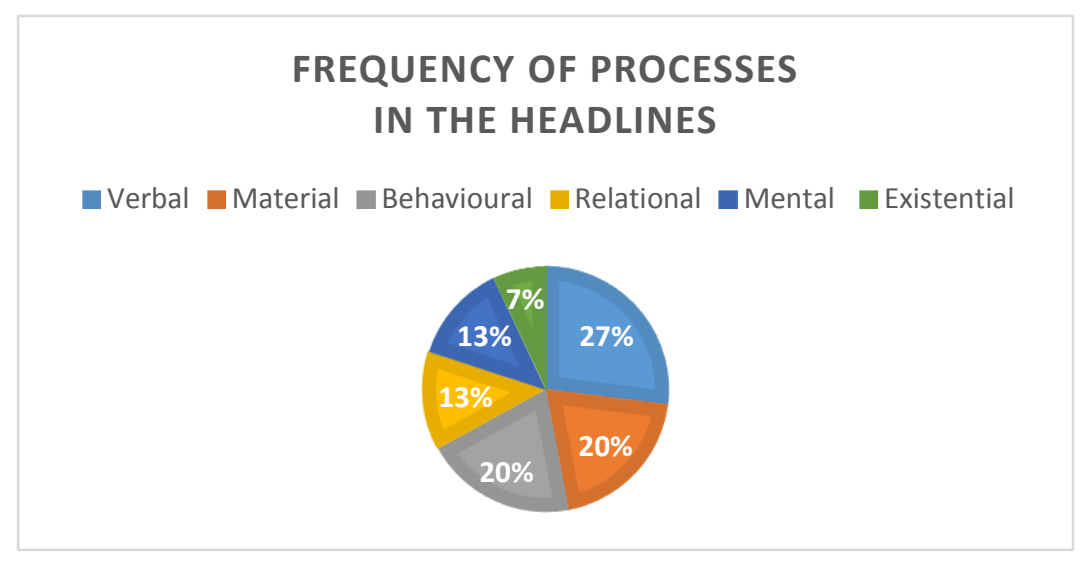

Figure 1. The distribution of transitivity processes in the headlines.

Figure 1 illustrates the distribution of transitivity processes, which in turn determine the importance of the patterns in the headlines.

\subsection{Verbal Process}

H.1 and H.2 include verbal processes. They are from CNN on $15^{\text {th }}$ and $16^{\text {th }}$ March 2019 respectively.

H.1: “Cricket journalist recounts harrowing day in New Zealand.”

H.2: "Man describes confronting New Zealand shooting suspect." 


\begin{tabular}{|r|c|c|c|c|}
\hline H.1 & $\begin{array}{c}\text { Cricket } \\
\text { journalist }\end{array}$ & Recounts & harrowing day & in New Zealand \\
\hline \multirow{2}{*}{ H.2 } & Man & Describes & $\begin{array}{c}\text { confronting New Zealand } \\
\text { shooting suspect }\end{array}$ & \\
\cline { 2 - 5 } & Sayer & Verbal Process & Verbiage & Circumstance: Place \\
\hline
\end{tabular}

In the two instances above, there are two verbal processes of indicating (see Section 3). The sayers are "cricket journalist" and "man" who recount and describe a "harrowing day" and "confronting New Zealand shooting suspect". In Headline1 (henceforth abbreviated ' $H$ ') there is a circumstance of place that shows where the event took place, as represented by the prepositional phrase "in New Zealand". The grammatical style has an experiential value in the sense that the transitivity processes are presented with responsible agents. Thus, the explicit representation of the agent combined with the verbal process of transitivity guarantees the validity of the reports. However, the analysis has shown that there are material processes combined with the verbal ones. H.3 is a combination of verbal and material processes. It is from CNN on $16^{\text {th }}$ March 2019.

H.3: "Mass shooting suspect obtained his guns legally New Zealand prime minister says."

\begin{tabular}{|c|c|c|c|c|c|c|}
\hline H.3 & $\begin{array}{c}\text { Mass } \\
\text { shooting } \\
\text { suspect }\end{array}$ & Obtained & his guns & legally & $\begin{array}{c}\text { New Zealand } \\
\text { prime minister }\end{array}$ & says \\
\cline { 2 - 7 } & Actor & $\begin{array}{c}\text { Material } \\
\text { Process }\end{array}$ & Goal & $\begin{array}{c}\text { Circumstance } \\
\text { Manner (degree) }\end{array}$ & Sayer & $\begin{array}{c}\text { Verbal } \\
\text { Process }\end{array}$ \\
\hline
\end{tabular}

In H.3, the material process is represented by the verb "obtained", and the actor is represented by "mass shooting suspect" and is followed by the goal, "his guns". Then a circumstance of manner, "legally", is used. The verbal process is represented by the verb "says" which is seen as an act of indicating, and the sayer is represented by "New Zealand Prime Minister". The verbiage is the whole material clause "Mass shooting suspect obtained his guns legally". Regarding the grammatical style, the action of obtaining the guns is projected with a responsible agent who legally owned his guns and such contribution cannot be presented without relating it to an authentic source. The next example shows the readers decisive decisions that politicians took in order to avoid such an act, as shown in H.4 below.

H.4 is a combination of verbal and material processes. It is from BBC on $17^{\text {th }}$ March 2019. 
H.4: "New Zealand gun laws will change PM says."

\begin{tabular}{|c|c|c|c|c|}
\hline \multirow{2}{*}{ H.4 } & $\begin{array}{c}\text { New Zealand gun } \\
\text { laws }\end{array}$ & will change & PM & Says \\
\cline { 2 - 4 } & Goal & $\begin{array}{c}\text { Material } \\
\text { Process }\end{array}$ & Sayer & Verbal Process \\
\hline
\end{tabular}

In H.4 there is a material process represented by the verb phrase "will change", the goal is the "New Zealand gun laws"; these elements are considered as verbiage for the verbal process "says", and the sayer is the Prime Minister "PM". What is stylistically significant about this headline is its use of relational modality. The verb group "will change" has a relational value, in the sense that it projects the $\mathrm{PM}$ as the one who has the power and authority to take such decisions. The use of the modal auxiliary "will" may be observed in threats or promises, and Jacinda Ardern, based on her institutional capacity, can issue such promises, as she has the ability to carry out an action that would again include the use of power.

\subsection{Material Process}

In the material process, the thematic role of goal is more frequent than actor. These goals are related to the victims and show the intensity of human damage: e.g., "forty-nine people", "48", "dozens of people", "many others". For example, the following headlines include two material processes each. H.5 is from BBC on the $15^{\text {th }}$ March 2019 and H.6 is from CNN on the $16^{\text {th }}$ March 2019.

H.5: "Forty-nine people have been killed and 48 wounded in shootings at two mosques in Christchurch, New Zealand."

H.6: "Dozens of people were killed and many others were seriously injured Friday afternoon when two mosques were attacked in Christchurch, New Zealand."

\begin{tabular}{|c|c|c|c|c|c|c|c|}
\hline H.5 & $\begin{array}{c}\text { Forty- } \\
\text { nine } \\
\text { people }\end{array}$ & $\begin{array}{c}\text { Have } \\
\text { been } \\
\text { killed }\end{array}$ & 48 & Wounded & - & in shootings & $\begin{array}{c}\text { at two mosques } \\
\text { in } \\
\text { Christchurch, } \\
\text { New Zealand. }\end{array}$ \\
\hline H.6 & $\begin{array}{c}\text { Dozens } \\
\text { of } \\
\text { people }\end{array}$ & $\begin{array}{c}\text { were } \\
\text { killed }\end{array}$ & $\begin{array}{c}\text { many } \\
\text { others }\end{array}$ & $\begin{array}{c}\text { were } \\
\text { seriously } \\
\text { injured }\end{array}$ & $\begin{array}{c}\text { Friday } \\
\text { afternoon when } \\
\text { two mosques } \\
\text { were attacked }\end{array}$ & in \\
Goal & $\begin{array}{c}\text { Material } \\
\text { Process }\end{array}$ & Goal & $\begin{array}{c}\text { Material } \\
\text { Christchurch, } \\
\text { Process }\end{array}$ & $\begin{array}{c}\text { Time } \\
\text { Timealand. }\end{array}$ & $\begin{array}{c}\text { Circumstance: } \\
\text { Manner }\end{array}$ & $\begin{array}{c}\text { Circumstance: } \\
\text { Place }\end{array}$ \\
\hline
\end{tabular}

In these examples, the actor is eliminated. In H.5, the verbs "killed" and "wounded" represent the material processes. Meanwhile, they are represented in the verbs "killed" and "injured" in H.5. In H.6, the goals are represented by "forty-nine people" and "48". In H.6, they are represented by "dozens" and "many others" as the entities affected by the actions which show the intensity of human damage caused by the attack. Also, there are circumstantial elements attached to the headlines. In H.5, the prepositional phrase "in shootings" is seen as a circumstance 
of manner that shows how people are "killed and wounded" because it entails how the action was done. In addition, there are circumstances of place and time attached to the headlines. In H.5 and H.6, the circumstances "at two mosques in Christchurch, New Zealand" and "in Christchurch, New Zealand", show where the attack took place. In H.6, the circumstance of time shows the time of the attack and is represented by "Friday afternoon" with a time clause "when two mosques were attacked" that modifies it. The objects in these examples are turned into subjects of equivalent passive sentences. The use of passivisation as a grammatical feature has an experiential value in the sense that the action is represented as an event with no responsible agent and the headlines answer the question "what has happened?" rather than "what did the subject do?". In terms of style, the grammatical choice implies that the absence of the agency foregrounds another issue, which is the patient in this case. Which stylistically serves a tacit ideological purpose of suppressing the identity of the attacker. However, it was found that some headlines did include an actor. For example, H.7 includes a material process of doing. It is from $\mathrm{CNN}$ on the $16^{\text {th }}$ March 2019.

\section{H.7: "A father of 4 confronted the New Zealand shooter."}

\begin{tabular}{|c|c|c|c|}
\hline H.7 & A father of 4 & Confronted & the New Zealand shooter \\
\cline { 2 - 3 } & Actor & Material Process & Goal \\
\hline
\end{tabular}

In H.7, the actor is mentioned and represented by "a father of 4" followed by a material process represented by the verb "confronted" and the entity affected by the action, as the goal, represented by "the New Zealand shooter." This headline is a simple sentence of Subject + Verb + Object structure and the use of activisation as a grammatical feature has an experiential value; that is to say, in terms of the representation of the social actor, the process is projected as an action with a responsible agent. Abdullahi-Idiagbon and Akeem (2017) argued that the material processes are important to reveal what the actors have done. In this case, the agent is highlighted and involved in a process that has a positive sense "confronting" in this particular context. According to the Longman Dictionary of Contemporary English (2019) (henceforth LDOCE), the verb "to confront" is defined as: "to deal with something very difficult or unpleasant in a brave and determined way" which juxtaposes the roles of the 'hero' versus the 'villain.'

\subsection{Behavioural Process}

H.8 \& 9 below, include physiological behavioural processes. H.8 is from BBC on the $16^{\text {th }}$ March 2019 and H.9 is from CNN on the $15^{\text {th }}$ March 2019.

H.8: "The New Zealanders rallying to help victims."

H.9: "Within hours of the Christchurch mosque attacks, people of various faiths rallied around Muslims." 


\begin{tabular}{|c|c|c|c|c|c|}
\hline H.8 & - & $\begin{array}{c}\text { The New } \\
\text { Zealanders }\end{array}$ & rallying & to help victims & \\
\hline H.9 & $\begin{array}{c}\text { Within hours of } \\
\text { the Christchurch } \\
\text { mosque attacks }\end{array}$ & $\begin{array}{c}\text { people of various } \\
\text { faiths }\end{array}$ & Rallied & - & around Muslims \\
\cline { 2 - 6 } & $\begin{array}{c}\text { Circumstance: } \\
\text { Time }\end{array}$ & Behaver & $\begin{array}{c}\text { Behavioural } \\
\text { Process }\end{array}$ & $\begin{array}{c}\text { Circumstance: } \\
\text { Cause: } \\
\text { (Purpose) }\end{array}$ & $\begin{array}{c}\text { Circumstance: } \\
\text { Projection } \\
\text { (Matter) }\end{array}$ \\
\hline
\end{tabular}

In the two examples above, "the New Zealanders" and "people of various faith" represent the behavers. "rallying" and "rallied" are the behavioural processes. In H.8, there is a circumstance of cause, namely, purpose that by its nature has the sense of 'in order to' and is represented by the prepositional phrase "to help victims" which helps to show the New Zealanders' end. However, in H.9 the circumstantial element "within hours of the Christchurch mosque attacks" shows the time, and "around Muslims" shows the matter. The grammatical style of these headlines has an experiential value in the sense that they represent the action with responsible agents. The behavers in these examples are involved in a physiological behavioural action that is psychologically motivated and is seen as 'an outer manifestation of inner workings'. This is further shown by the sense of the verb "rally" in conformance with the context and its meaning according to LDOCE (2019) which defines it as "to come together, or to bring people together, to support an idea, a political party." At the level of vocabulary, the choices that are made to represent the behavers/ agents "the New Zealanders" and "people of various faiths" are ideologically significant and have positive expressive values by showing the solidarity of the people of New Zealand regardless of their religion, and the non-discrimination of race policy held by the country. These ideas are further supported by attaching the circumstantial elements to the headlines. In H.8, "to help victims" shows the purpose. Meanwhile in H.9, "within hours of the Christchurch mosque attacks" shows the time of the action, which entails their quick response, and "around Muslims" projects the matter. The other behavers are related to the victims and their families. For example, H.10 is from BBC on the $16^{\text {th }}$ March 2019.

H.10: "Victim's brother speaks of pain."

\begin{tabular}{|c|c|c|c|}
\hline H.10 & Victim's brother & Speaks & of pain \\
\cline { 2 - 4 } & Behaver & $\begin{array}{c}\text { Behavioural } \\
\text { Process }\end{array}$ & Circumstance: Manner (quality) \\
\hline
\end{tabular}

In the example above, the behavioural process is represented by the verb "speaks". "Victim's brother" represents the behaver and there is a circumstance of manner that shows the way in which the victim's brother speaks. As far as the structural style is concerned, this headline again has the experiential value of representing the action with a responsible agent. The behaver is a brother of a 
victim and this choice at the level of vocabulary expresses the struggles and sufferings that the victims, as well as their families, have experienced. In this case, the process is considered as behavioural rather than verbal because of the meaning of the verb "speak" according to LDOCE (2019), which offers a sense of expressing feelings and opinions in such contexts 'to say something that expresses your ideas or opinions.' This idea is further supported by the circumstance "of pain" that shows the manner and more specifically the quality of expressing the pain, in conformance with the definition of the process which is again seen as 'an outer manifestation of inner workings' as in the example 9 (See section 3).

\subsection{Relational Process}

H.11 and H.12 include two relational processes of identifying (see Section 3). H.11 is from BBC on $15^{\text {th }}$ March 2019, and H.12 is from CNN on $16^{\text {th }}$ March 2019

H.11: "This is one of New Zealand's darkest days."

H.12: "American Muslims are horrified by the New Zealand attacks."

\begin{tabular}{|c|c|c|c|c|}
\hline H.11 & 'This & Is & $\begin{array}{c}\text { one of New Zealand's darkest } \\
\text { days' }\end{array}$ & - \\
\hline \multirow[t]{2}{*}{ H.12 } & $\begin{array}{l}\text { American } \\
\text { Muslims }\end{array}$ & Are & Horrified & $\begin{array}{c}\text { by the New Zealand } \\
\text { attacks. }\end{array}$ \\
\hline & Token & $\begin{array}{c}\text { Relational } \\
\text { Process }\end{array}$ & Value & $\begin{array}{c}\text { Circumstance: Cause } \\
\text { (Reason) }\end{array}$ \\
\hline
\end{tabular}

In the two instances above, there are two relational processes represented by "is" and "are". In H.11, "this" is classified as the token and it refers to the day of the attack which has been further described as "one of New Zealand's darkest days". Moreover, in H.12, the token "American Muslims" are described as being horrified by "the New Zealand attacks" and this is considered as a circumstance of cause in which the readers get the reason for this value. In H.11, it can be seen that the style of using the metaphor is ideologically motivated. In the sense that, the metaphorical representation of this social problem i.e. "New Zealand's darkest days" entails that terrorism is not common in the society of New Zealand. H.12 shows a relationship of being type i.e. $\mathrm{X}$ is $\mathrm{Y}$, which in turn expresses a value that has been assigned to "American Muslims" who are shocked by what happened in New Zealand and their fear of the transferability of violence to their society.

\subsection{Mental Process}

H.13 includes two perceptive mental processes. It is from CNN on 18th March 2019. Meanwhile H.14 includes an emotive mental process (see Section 3). It is from BBC on $16^{\text {th }}$ March 2019

H.13: "A quiet country reels after a horrific massacre and struggles to find its new normal." 
H.14: "New Zealand mourns victims."

\begin{tabular}{|c|c|c|c|c|c|c|}
\hline H.13 & $\begin{array}{c}\text { A quiet } \\
\text { country }\end{array}$ & Reels & - & $\begin{array}{c}\text { after a horrific } \\
\text { massacre }\end{array}$ & $\begin{array}{c}\text { and } \\
\text { struggles }\end{array}$ & $\begin{array}{c}\text { to find its new } \\
\text { normal }\end{array}$ \\
\hline H.14 & $\begin{array}{c}\text { New } \\
\text { Zealand }\end{array}$ & Mourns & victims & - & - & - \\
\cline { 2 - 7 } & Senser & $\begin{array}{c}\text { Mental } \\
\text { Process }\end{array}$ & Phenomenon & $\begin{array}{c}\text { Circumstance: } \\
\text { Cause (Reason) }\end{array}$ & $\begin{array}{c}\text { Mental } \\
\text { Process }\end{array}$ & $\begin{array}{c}\text { Circumstance: } \\
\text { Cause (Purpose) }\end{array}$ \\
\hline
\end{tabular}

In H.13, there are two perceptive mental processes represented by the verbs "reels" and "struggles". "A quiet country" represents the senser. Also, there are two types of cause circumstances; the first one shows the reason of cause represented by "after a horrific massacre" and the second one reflects the cause's purpose in the phrase "to find its new normal". Furthermore, in H.14, the senser is "New Zealand", followed by the emotive mental process, "mourns", and the phenomenon represented by "victims". The grammatical style of the two examples above expresses the value of representing the actions with responsible agents that are the sensers' elements in the mental transitivity action. They are represented by "a quiet country" and "New Zealand" and this use is ideologically motivated in the sense that the inanimate agents are given animacy that is the ability of the country to "reel" and "mourn" by means of personification. Which is a metaphorical device to emphasise the sympathy of the New Zealand community and all its denominations with the victims.

\subsection{Existential Process}

The last type of process in this study is the existential, which is represented in H.15; it includes an existential process that is classified as circumstantial (see Section 3). It is from BBC on 18th March 2019.

H.15: "The Christchurch mosque attacks were live-streamed on the internet."

\begin{tabular}{|c|c|c|c|}
\hline \multirow{2}{*}{ H.15 } & $\begin{array}{c}\text { The Christchurch mosque } \\
\text { attacks }\end{array}$ & were live-streamed & on the internet \\
\cline { 2 - 4 } & Existent & Existential Process & Circumstance: Place \\
\hline
\end{tabular}

In the example above, there is a circumstantial existential process that is used to show the existent i.e. "The Christchurch mosque attacks" as an entity that exists in a place. In this sense, the circumstance is "on the internet" and the existential process is realised by the verb group "were live-streamed".

\section{Conclusion}

The discussion and results presented in the previous section revealed that there are stylistic similarities between the two agencies in terms of the style of reporting and discursive strategies. For instance, it is noted that BBC and CNN tend to suppress the identity of the attacker and highlight the role of the victims in order to dramatize the attack. Such style of reporting is used to conform with the New Zealand 
government policy which declared that the identity of the attacker should never be negotiated among people or spoken of. In addition, this section offers the following conclusions about the style of reporting in each type of process. These conclusions confirm Halliday's (2004) assumptions about what each type of process can construct in the mental, physical, social, and psychological worlds.

First, the style of constructing verbal experiences enables news' reporters to contribute information to eyewitnesses as in the example H.1 "cricket journalist recounts harrowing day in New Zealand" and to officials as in the example, H.3: "Mass shooting suspect obtained his guns legally New Zealand Prime Minister says". Verbal processes in this sense are seen as important stylistic resources of the creation of narrative, as they make it possible to set up dialogic passages. Moreover, such use of verbal processes in news reporting helps the language users to contribute information to sources and putting the thoughts into words.

Second, adopting material processes in the reporting of the headlines is seen as suitable to the style of constructing a quantum of changes that took place in the New Zealand Mosque Massacre event to represent the physical harm in the form of death and injury. This can be seen in H.5, "Forty-nine people have been killed and 48 wounded in shootings at two mosques in Christchurch, New Zealand." and H.6 "Dozens of people were killed and many others were seriously injured Friday afternoon when two mosques were attacked in Christchurch, New Zealand." The material processes "killed," "wounded," and "injured" are constructions of experiences made by language users (news reporters in this case).

Third, the style of reporting behavioural processes help reporters to make sense of human physical actions that are psychologically motivated, for example, H.8 "the New Zealanders rallying to help victims." and H.10: "victim's brother speaks of pain". In H.8, the process "rally" construes a material-behaviour, while the use of the verb "speak" in H.10 construes a mental-behaviour as it reflects a sense of expressing feelings, more specifically, pain. In this sense, the behavioural processes "rallying" and "speaks of" have no clearly defining characteristics; they are partly like the material and partly like the mental.

Fourth, in terms of constructing attributive relational processes, the act of referring through the use of the pronoun "this" in H.11 "this is one of New Zealand's darkest days" helps in construing a relationship of 'being' rather than a phenomenon of consciousness. This element is configured with another relational participant "is" which has a semiotic property that can be attributed to the act of the Christchurch Mosque Massacre which is further described as "one of New Zealand's darkest days." In this sense, the relational process models the style of this experience as 'being' rather than 'doing'. Thus, the use of copular "is" is construed not only with things as participants, but also with acts and facts, and it resembles to mental experience.

Fifth, the style of modelling mental experiences is similar to the material processes where their constructions help to construe a quantum of change in the flow of the event and are seen as a sequence of changes. Yet, these changes in the mental experiences are in the world of consciousness rather than the physical world of material processes. In the case of this study, the world of consciousness is related 
to the New Zealand Massacre, which constructs mental changes in the society that is represented by processes, such as: "reeling," "struggling," and "mourning". H.13 and 14 illustrate this point: "A quiet country reels after a horrific massacre and struggles to find its new normal," and "New Zealand mourns victims".

Last but not least, existential processes serve the style of determining central participants in placement (setting and orientation). The example discussed in H.15 demonstrates that the existential experience is construed to introduce a phenomenon (setting) i.e. "The Christchurch mosque attacks" into a material stream of narration (orientation) "were live-streamed" in conjunction with a circumstance of place "on the internet." again (setting).

Finally, it is worth mentioning that the analysis presented by the researchers about the transitivity style of news reporting is tentative and by no means exhaustive. Further research is needed to further validate the conclusions of this study. In short, the value of this study would be greatly enriched by further study into public discourse on this particular issue, as well as from additional applications of the methods chosen for the analysis, as both would provide welcome examples for comparison, conducive to a more nuanced interpretation of the results outlined herein.

Mohammed Al-Badawi

English Language and Literature Department

Zarqa University, Jordan

ORCID Number: 0000-0002-3594-7339

Email: Badawi80_mohammad@yahoo.com

Ibrahim Al Najjar

English Language and Literature Department

Zarqa University, Jordan

ORCID Number: 0000-0002-8083-2338

Email: inajjar9@gmail.com

\section{References}

Abdullahi-Idiagbon, Mohammed and Ameen Akeem. (2017). 'Ideological perspectives in editorial: a critical study of hallmark editorial'. International Journal of Arabic- English Studies, 17 (1), 47.

Abbas, Muhammad and Mubina, Talaat. (2019). 'Transitivity analysis of newspapers' news-headlines depicting crime committed against women in Pakistan'. International Journal of English Linguistics, 9 (5), 400. doi:10.5539/ijel.v9n5p400. 
Al Najjar, Ibrahim. (2020). Discursive strategies of political discourse about Christchurch mosque massacre in New Zealand. Unpublished thesis, Zarqa University, Zarqa'a, Jordan.

BBC. (2020). https://www.bbc.com/ (Retrieved on 15 March 2020)

CNN International - Breaking News. (2020). US News, World News and Video. https://www.cnn.com/ (Retrieved on 10 March 2020)

Halliday, Michael. (1994). An Introduction to Functional Grammar. London: Edward Arnold.

Halliday, Michael. (2004). An Introduction to Functional Grammar. London: Hodder Education.

Jin, Xie. (2015). 'A critical analysis of the Diaoyu Islands Dispute in American news media'. International Journal of English Linguistics, 5 (2). doi:10.5539/ijel.v5n2p55

Longman Dictionary of Contemporary English | LDOCE. (2020). https://www.ldoceonline.com/ (Retrieved on 15 March 2020).

Maghfiroh, Laylatul. (2017). The transitivity analysis of the news headlines of the Jakarta Post. Unpublished thesis, Walisongo University, Semarang, Indonesia.

Miranti, Ika. (2014). Transitivity Analysis in the Construction of Newspaper Ideology: A Comparative Study on the New York Times and the Washington Times' Editorials. Unpublished thesis, Dian Nuswantoro University, Semarang, Indonesia.

New York Police Department. (2020). https://www1.nyc.gov/site/nypd/index.page/ (Retrieved on 22 June 2020).

Ong'onda, Nancy. (2016). 'Transitivity analysis of newspaper headlines on terrorism attack in Kenya: A case study of Westgate Mall, Nairobi'. International Journal of Humanities and Social Science, 6 (9).

Radio New Zealand. (2020). 'Mosque attacks timeline: 18 minutes from first call to arrest'. https://www.rnz.co.nz/news/national/387248/mosque-attackstimeline-18-minutes-from-first-call-to-arrest (Retrieved on 15 May, 2020).

Seo, Soa. (2013). 'Hallidayean transitivity analysis: the battle for Tripoli in the contrasting headlines of two national newspapers'. Discourse \& Society, 24 (6), 774-791. doi: 10.1177/0957926513503267

Simpson, Paul. (2003). Language, Ideology and Point of View. London: Routledge.

Simpson, Paul. (2014). Stylistics: A Resource Book for Students. Milton Park, Abingdon, Oxon: Routledge. 